\title{
ESSAY
}

\section{FEDERAL FUNCTIONS: EXECUTION OF POWERS THE CONSTITUTION GRANTS TO PERSONS AND ENTITIES OUTSIDE THE U.S. GOVERNMENT}

\author{
by Robert G. Natelson
}

ABSTRACT

The Constitution grants enumerated powers to officers and agencies of the federal government. What is less widely understood is that it also grants extensive powers to persons and entities entirely outside the federal government. The courts refer to the exercise of those powers as "federal functions."

This short Essay is the first unified survey of those federal functions. It classifies them and identifies certain commonalities and differences.

\section{INTRODUCTION}

Much of the Constitution consists of enumerated powers. Perhaps the best-known enumeration is the extensive list of powers granted to Congress in Article I, Section 8.' Shorter lists appear in Article II (granting authority to the president) ${ }^{2}$ and Article III (granting authority to the judiciary). ${ }^{3}$ In addition, the Constitution grants a few powers to the United States government as an entity. ${ }^{4}$ When officers and agencies of, and contractors with, the federal

Professor of Law (ret.), The University of Montana; Senior Fellow in Constitutional Jurisprudence, the Independence Institute, Denver. The author acknowledges the assistance of Jacob Meckler, George Mason School of Law, Class of 2022, and Rita Dunaway, J.D. Washington and Lee University, Class of 2001.

U.S. CONST. art. I, $\S 8$.

Id. art. II, \$\$ 2-3; see Robert G. Natelson, The Original Meaning of the Constitution's "Executive Vesting Clause"-Evidence from Eighteenth-Century Drafting Practice, 31 WhitTiER L. REv. 1, 35 (2009) (finding that the frequent claim that the first clause of the Constitution is a grant of "Executive Power" and that Sections 2 and 3 merely clarify its scope is inconsistent with the drafting practice applied to the Eighteenth Century power-granting institutions).

U.S. CONST. art. III, $\$ 2$.

See Robert G. Natelson, More News on the Powers Reserved Exclusively to the States, 20 FEDERALIST SOC'Y REV. 92, 95-96 (2019) (discussing grants to the government in Articles IV and VI of the Constitution). 
government execute these powers those actors are exercising federal functions. ${ }^{5}$

In addition, many of the Constitution's provisions bestow authority on persons or entities that are neither part of, nor contractors with, the federal government. The usual course of business of many of these actors is to carry out duties unrelated to the Constitution. For example, state governors, legislatures, and governments normally operate under their state constitutions. However, the Constitution gives them federal responsibilities as well. Similarly, Congress, which normally serves as the federal legislature, also receives specific authority from the Constitution's provisions for amendment. ${ }^{6}$ Congress exercises its amendment authority as an independent assembly representing the people directly, rather than as the federal legislature.

The Constitution grants other powers to persons and entities not part of any government at all. These grantees include conventions for proposing and ratifying constitutional amendments, presidential electors, jurors, and federal election voters. The courts likewise characterize these non-federal persons and entities as exercising federal functions.

To date, there has been no scholarly literature addressing the general classes of federal functions exercised by non-federal actors or their commonalties and differences. Instead, scholarly attention has been focused on particular institutions, such as the Electoral College ${ }^{8}$ and the conventions and legislatures acting in the amendment process. ${ }^{9}$ This Essay is designed to

See, e.g., United States v. Bedford, 914 F.3d 422, 429-30 (6th Cir. 2019) (holding that an employee of a U.S. government contractor performs a federal function); see also Commodities Exp. Co. v. Detroit Int'l Bridge Co. 695 F.3d 518, 529 (6th Cir. 2012) (referring to "federal agencies that perform federal functions").

U.S. CONST. art. V.

See infra note 30 and accompanying text.

${ }^{8}$ See Christopher Anglim, A Selective, Annotated Bibliography on the Electoral College: Its Creation, History, and Prospects for Reform, 85 LAW LiBR.J. 297, 297-99 (1993) (focusing on the presidential selection process regarding the Electoral College, rather than examining the "federal function" aspects).

9 See Robert G. NATElson, The LAW OF ARticle V: State Initiation OF CONSTitutional AMENDMENTS 56 (2d ed. 2020) [hereinafter NATElSON, LAW OF ARTicle V] (highlighting the convention call in the amendment process); see also Robert G. Natelson, Is the Constitution's Convention for Proposing Amendments a "Mystery". Overlooked Evidence in the Narrative of Uncertainty, 104 MARQ. L. REv. (forthcoming Dec. 2020) [hereinafter Natelson, Mystery] (explaining how the "convention of states" applies to the Constitution); Robert G. Natelson, Founding-Era Conventions and the Meaning of the Constitution's "Convention for Proposing. 
fill the gap and in part to provoke more examination. It draws partly on my previous research into the Elections Clause, ${ }^{10}$ the amendment process, ${ }^{11}$ and the presidential election system. ${ }^{12}$

\section{Classification of Federal FunCtions}

The Supreme Court first applied the term "federal function" to the actions of a non-federal entity in the 1922 case of Leser v. Garnett..$^{13}$ Justice Louis Brandeis wrote the opinion of the Court. Justice Brandeis found that a state legislature's power to ratify a constitutional amendment derived directly from the Constitution rather than from any reserved state authority and that the ratification procedure was governed wholly by Article $\mathrm{V}$ and could not be altered by state constitutions or laws. ${ }^{14}$ Since that decision, courts at all levels have applied the term "federal function" to the execution of constitutional powers by non-federal actors.

In 2015 the Court decided Arizona State Legislature v. Arizona Independent Redistricting Commission. ${ }^{15}$ That case grouped many of these federal functions into classes. The Court defined the classes as electoral,

Amendments," 65 FLA. L. REv. 615, 629 (2013) [hereinafter Natelson, Conventions] (discussing convention terminology); Robert G. Natelson, Proposing Constitutional Amendments by Convention: Rules Governing the Process, 78 Tenn. L. Rev. 693, 696 (2011) [hereinafter Natelson, Rules] (focusing on convention calls and the roles of legislatures within the convention process).

10 See generally Robert G. Natelson, The Original Scope of the Congressional Power to Regulate Elections, 13 U. PA. J. CONST. L. 1 (2010) [hereinafter Natelson, Original Scope] (examining the intended scope of Congress's enumerated power to regulate the "Times, Places and Manner of holding Elections”). In Arizona State Legislature v. Arizona Independent Redistricting Commission, Chief Justice Roberts cited to that article for the proposition that Anti-Federalists supported vesting election regulation power solely in state legislatures. 135 S. Ct. 2652, 2684 (2015) (Roberts, C.J., dissenting).

$11 \quad I d$.

12 See Rob Natelson, Presidential Elector Discretion: The Originalist Evidence, Originalism Blog (Jan. 4, 2018), https://originalismblog.typepad.com/the-originalism-blog/2018/01/president-electordiscretion-the-originalist-evidence-part-2rob-natelson.html [hereinafter Natelson, Discretion] (highlighting the process of choosing a president); Rob Natelson, Elector Discretion: A Response to John Vlahoplus, ORIGINALISM BLOG (Apr. 4, 2020), https://originalismblog.typepad.com/theoriginalism-blog/2020/04/elector-discretion-a-response-to-john-vlahoplusrob-natelson.html (responding to John Vlahoplus's Bound Electors). But see John Vlahoplus, Bound Electors, 106 VA. L. REv. ONLINE 1, 9 (2020) (claiming that electors may be bound). 258 U.S. 130, 137 (1922).

Id.

Ariz. St. Legis., 135 S. Ct. at 2652. 
ratifying, legislative, appointive, and consenting. ${ }^{16}$ This Essay employs those designations. It further identifies three additional classes: administrative, proposing, and judicial.

\section{A. Electoral Functions}

The Constitution grants certain non-federal actors power to participate in federal elections. ${ }^{17}$ Although presidential electors are not officers of the federal government, ${ }^{18}$ when they vote for president and vice president ${ }^{19}$ they "exercise federal functions under, and discharge duties in virtue of authority conferred by, the Constitution of the United States." ${ }^{20}$ Similarly, the Constitution empowers the states to choose presidential electors in the manner their legislatures direct. ${ }^{21}$ It designates as congressional "Electors" those people who have the qualifications requisite for electors of the most numerous branch of their respective state legislatures. ${ }^{22}$ Congressional electors derive their power from the Constitution and exercise a federal electoral function when they cast their ballots. ${ }^{23}$ Before ratification of the Seventeenth Amendment, ${ }^{24}$ state legislatures served an electoral function when they elected United States Senators. ${ }^{25}$

\footnotetext{
Id. at 2667-68 (distinguishing electoral, appointive, consenting, ratifying, and legislative functions). Id. at 2667 (describing the authority to select United States Senators granted to state legislatures by Article 1, Section 3 prior to the enactment of the Seventeenth Amendment).

18 Burroughs v. United States, 290 U.S. 534, 545 (1934) (highlighting that "presidential electors are not officers or agents of the federal government (citing In re Green, 134 U.S. 377, 379 (1890)).

19 U.S. CONST. art. II, $\$ 1$, cl. 3.

20 Burroughs, 290 U.S. at 545.

${ }_{21}$ U.S. CONST. art. II, $§ 1$, cl. 2; McPherson v. Blacker, 146 U.S. 1, 25, 34-35 (1892) (observing that the Constitution grants state legislatures "plenary authority to direct the manner of appointment" of presidential electors for their states and that state legislatures may appoint electors directly); see also Chiafalo v. Washington, 140 S. Ct. 2316, 2320 (2020) (holding that "a State may . . penalize an elector for breaking his pledge and voting for someone other than the presidential candidate who won his State's popular vote.").

${ }^{22}$ U.S. CONST., art. I, $\$ 2$, cl. 1 (election of Representatives); id. amend. XVII, cl. 1 (election of Senators).

${ }^{23}$ Ex parte Yarbrough, 110 U.S. 651, 662-64 (1884) (stating that the Constitution grants the function of casting a vote for members of Congress).

24 U.S. CONST. amend. XVII.
}

${ }_{25} \quad I d$. art. I, § 3, cl. 1 . 


\section{B. Appointive Functions}

Before ratification of the Seventeenth Amendment, governors enjoyed direct authority to make vacancy appointments to the Senate. ${ }^{26}$ Under the Seventeenth Amendment, governors still make vacancy appointments to the Senate if authorized by their respective state legislatures. ${ }^{27}$ Under Article V, Congress exercises an appointive function when it determines whether state legislatures or state conventions will ratify or a reject a proposed constitutional amendment. ${ }^{28}$

\section{Proposing and Ratifying Functions}

The Constitution grants Congress power to propose amendments. ${ }^{29}$ When Congress acts in the amendment process, it does so as an independent body representing the people rather than as the federal legislature. ${ }^{30}$ The document further grants authority to state legislatures make "Application" to Congress to call a "Convention for proposing Amendments," and when two thirds of the states apply, issuing the call is mandatory. ${ }^{31}$ The state legislatures' ability to compel Congress to act is, therefore, a branch of the proposal poweralthough authority to issue final proposed amendments rests with the

${ }_{26} \quad I d$. art. I, § 3, cl. 2.

${ }^{27}$ Id. amend. XVII, cl. 2. The Supreme Court labeled this an "appointive function" in Arizona State Legis. 135 S. Ct. at 2668 n.17.

${ }_{28} \quad$ U.S. CONST. art. V.

$29 \quad I d$.

30 See In re Op. of the Justs., 107 A. 673, 674 (Me. 1919) ("Nor is Congress, in proposing constitutional amendments, strictly speaking, acting in the exercise of ordinary legislative power. It is acting in behalf of and as the representative of the people of the United States under the power expressly conferred by Article V.”); see also Idaho v. Freeman, 529 F. Supp. 1107, 1127-28 (D. Idaho 1981) (stating that when acting in the amendment process Congress is not acting pursuant to its Article I legislative powers), vacated as moot, Carmen v. Idaho, 459 U.S. 809 (1982); see also Hollingsworth v. Virginia, 3 U.S. 378, 381 (1798) (holding the congressional proposal of an amendment is not part of the legislative process, so presentment to the president is unnecessary).

${ }^{31}$ U.S. CONST. art. V (" $[\mathrm{O}] \mathrm{n}$ the Application of the Legislatures of two thirds of the several States, [Congress] shall call a Convention for proposing Amendments[.]"). Although the Constitution calls this gathering a "Convention for proposing Amendments," in recent years it has become common to refer to it as a "constitutional convention." This misnomer is deceptive, because Article V grants the convention only power to "propose Amendments to this Constitution," not power to write a new one. Id. (emphasis added). The convention for proposing amendments is one of three kinds of conventions the Constitution authorizes. The others were established to ratify or reject the Constitution itself, $i d$. art. VII, and to ratify or reject proposed amendments, $i d$. art. V. 
convention. ${ }^{32}$ The Constitution also empowers state legislatures and state conventions to execute ratifying functions by approving (or rejecting) proposed amendments. $^{33}$

\section{Administrative Functions}

The Constitution assigns to Congress the administrative functions of (1) calling a convention for proposing amendments when required by two thirds of the states ${ }^{34}$ and (2) counting electoral votes in presidential elections. ${ }^{35}$ Other administrative functions include a state governor's authority to issue writs of election to fill vacancies in the House of Representatives ${ }^{36}$ and like authority to issue writs of election to fill vacancies in the Senate. ${ }^{37}$

\section{E. Legislative Functions}

The Elections Clause ${ }^{38}$ grants authority to "the Legislature" of each state to regulate the times, places, and manner of congressional elections. ${ }^{39}$ However, the grant is not to state legislatures alone, but to the entire legislative apparatus of each state. This apparatus encompasses, where applicable, initiative and

${ }_{32}$ See U.S. CONST. art. V. (providing that Congress or a "Convention for proposing Amendments" rather than the state legislatures, shall propose amendments).

33. See Arizona State Legis., 576 U.S. at 806 (contrasting the ratifying function, exercisable exclusively by state legislatures, with the "ordinary business of legislation").

${ }^{34}$ U.S. CONST. art. V. The normal scope of this kind of convention call is quite narrow, designating merely time, place, and subject for meeting. NATELSON, LAW OF ARTICLE V, supra note 9, at 5557.

${ }^{35} \quad$ U.S. CONST. amend. XII.

36 Id. art. I, $\$ 4$, cl. 1 .

${ }_{37} \quad$ Id. amend. XVII, cl. 2.

${ }_{38} I d$. art. I, $\S 4, \mathrm{cl} 1$. Although the Supreme Court refers to this as the Elections Clause, a more accurate title is Times, Places and Manner Clause, a term adopted by several commentators. See, e.g., Robert E. Ross \& Barrett Anderson, Single-Member Districts Are Not Constitutionally Required, 33 ConsT. Comment. 261, 263 (2018); Natelson, Original Scope, supra note 10, at 1; Paul E. McGreal, Unconstitutional Politics, 76 NOTRE DAME L. Rev. 519, 553 (2001). The term "Times, Places, and Manner Clause" is preferable to distinguish it from other "elections clauses" scattered throughout the Constitution. See U.S. CONST., art. I, § 2, cl. 1 (describing the election of Representatives); id. art. II, § 1 (describing the election of the President); id. amend. XII (revising portions of Article II, Section I describing the election of the President); id. amend. XVII, cl. 1 (describing the election of Senators).

$39 \quad$ U.S. CONST. art. I, \$ 4 cl. 1; see also U.S. Term Limits, Inc. v. Thornton, 514 U.S. 779, 805 (1995) (characterizing the Elections Clause as an "express delegation[l of power to the States to act with respect to federal elections"). 
referendum procedures, ${ }^{40}$ and signature by the governor. ${ }^{41}$ The Constitution also grants (subject to some exceptions) lawmaking authority to state legislatures to regulate state choice of presidential electors. ${ }^{42}$

\section{F. Consenting Functions.}

In Arizona State Legislature, the Supreme Court referred to the power of a state legislature to agree to acquisition of federal enclaves within state boundaries as a consenting function. ${ }^{43}$ In this instance, however, the grant is to the state legislature alone, exclusive of other state actors." Arizona State

40 See Arizona State Legis., 576 U.S. at 808 (holding that a state may, by voter initiative, vest power to draw congressional districts in an independent commission); see also Ohio ex rel. Davis v. Hildebrant, 241 U.S. 565, 569-70 (1916) (holding that state regulations under the Elections Clause are subject to referendum if mandated by the state constitution).

4 See Smiley v. Holm, 285 U.S. 355, 366 (1932) (reasoning that Elections Clause regulations require the governor's signature because "these requirements would be nugatory if they did not have appropriate sanctions in the definition of offenses and punishments"). The Supreme Court has not relied on originalist sources for its conclusion that the grant in the Elections Clause is to the entire state legislative apparatus rather than to the legislature as a free-standing assembly. However, such sources seem to support the Court's conclusion. Before the Constitution was ratified, American states typically regulated election by statute rather than by mere legislative resolution. Natelson, supra note 10, at 13-17. This practice continued for congressional elections immediately after ratification. Id. at 17 .

12 U.S. CONST. art. II, $\$ 1 \mathrm{cl}$. 2. Although the Constitution explicitly lodges regulation of the choice of presidential electors in the states, id., the Supreme Court has concluded that Congress also has authority to regulate presidential elections. Burroughs v. United States, 290 U.S. 534, 544 (1934). However, the source of that authority, aside from Congress's authority to designate the time for choosing electors and the day in which they vote, US. CONST. art. II, \$ 2, cl. 4, is unclear. Justice George Sutherland's opinion for the Court in Burroughs relied on Ex parte Yarbrough. Burroughs, 290 U.S. at 545-46. However, Yarbrough held only that the Elections Clause granted Congress implied power over congressional elections. 110 U.S. 651, 656-57 (1884) (reciting the terms of the indictments at issue); see also id. at 660 (relying on Article I, Section Four of the Constitution for its holding).

Despite efforts to classify Justice Sutherland as a judicial conservative, Alpheus Thomas Mason, The Conservative World of Mr. Justice Sutherland, 1883 - 1918, 32 AM. POL. SCI. Rev. 443, 471 (1938), he could be quite freewheeling about locating sources of federal power. See, e.g., United States v. Curtiss-Wright Export Corp., 299 U.S. 304, 316-17 (1936) (finding, despite the wording of the Tenth Amendment, that the federal government has inherent sovereign authority not enumerated in the Constitution).

43 Arizona State Legis., 135 S. Ct. at 2667.

" In McPherson, supra note 21, the court stated that the Constitution's specification that the legislature was to be the agency directing the manner of appointing presidential electors prevented a state from circumscribing the legislature's power. Id. at 25. The court added that "This power is conferred upon 
Legislature similarly denominated the legislative consent of existing states to creation of new states consisting of lands in existing states. ${ }^{45}$ Still another such function is the consent to federal action by state legislatures or executives under the Guarantee Clause. ${ }^{46}$

It is not entirely clear if the Constitution bestows the power to consent to enclaves or creation of new states on the legislature acting independently (as in Article V) or on the entire state legislative apparatus (as in the Elections Clause). Intuitively, however, it would seem that action effectively modifying state boundaries and territorial jurisdiction, and therefore fundamental provisions of the state constitution, should require more than a mere legislative resolution. The Supreme Court has lent incidental support to this position, ${ }^{47}$

the legislatures of the states by the constitution of the United States, and cannot be taken from them or modified by their state constitutions any more than can their power to elect senators of the United States." Id. at 35. It compared the Constitution's designation of the legislature alone as the state's agent for directing the manner of appointing presidential electors to the Constitution's designation of the state's delegation in the House of Representatives as its sole agent for voting in presidential runoff elections in the House. Id. at 26-27.

In the early days of the republic, Massachusetts adopted and changed the mode of choosing electors by simple resolution, without the signature of the governor, rather than by legislation. E.g., MAss RESOLVES, c. 6 (1800).

45 Arizona State Legis., 135 S. Ct. at 2668 n.17. In Article IV, the Constitution outlines creation of new states:

New States may be admitted by the Congress into this Union; but no new State shall be formed or erected within the Jurisdiction of any other State; nor any State be formed by the Junction of two or more States, or Parts of States, without the Consent of the Legislatures of the States concerned as well as of the Congress. U.S. CONST. art. IV, § 3, cl. 1

46 See U.S. CONST. art. IV, \$ 4 ("The United States ... shall protect each of them ... on Application of the Legislature, or of the Executive (when the Legislature cannot be convened) against domestic Violence.”.

47 The Court has characterized the consent necessary for federal acquisitions under the Enclave Clause as the consent of the state. See, e.g., Kleppe v. New Mexico, 426 U.S. 529, 541-42 (1976) (referring in several places to state rather than merely legislative consent); Paul v. United States, 371 U.S. 245, 264-65 (1963) (discussing whether the enclaves at issue were purchased by the consent of the California Legislature and highlighting the power of the Federal government to acquire land within a state without the consent of the state); Fort Leavenworth R. Co. v. Lowe, 114 U.S. 525, 530-33 (1885) (referring to consent of the state). However, the issue was not under adjudication in these cases; perhaps the Court used "consent of the state" language merely as shorthand for consent of the state legislature. 
as does historical practice, ${ }^{48}$ and James Madison's commentary in Number 43 of The Federalist. ${ }^{49}$

However, the text of the Guarantee Clause-vesting the power in the legislature or if the legislature cannot be convened, in the governor alonesuggests that the consent of each branch is given independently.

\section{G. Judicial Functions}

In several places, the Constitution conveys power through words of obligation or entitlement rather than explicit words of grant. ${ }^{50}$ The provisions requiring trial juries and grand juries ${ }^{51}$ are illustrative: They effectively empower federal officials to empanel juries and the juries to carry out their respective roles. These juries exercise federal judicial functions.

48 See, e.g., Virginia v. West Virginia, 78 U.S. 39 (1871) (discussing Virginia's consent to the creation of West Virginia by an act of ordinary legislation); United States v. Brown, 552 F.2d 817, 819 (8th Cir. 1977) (finding consent by Minnesota to a federal enclave from the totality of that state's conduct).

${ }_{19}$ In referring to the capital district and other federal enclaves, James Madison commented:

And as it is to be appropriated to this use with the consent of the State ceding it; as the State will no doubt provide in the compact for the rights and the consent of the citizens inhabiting it; as the inhabitants will find sufficient inducements of interest to become willing parties to the cession; as they will have had their voice in the election of the government which is to exercise authority over them; as a municipal legislature for local purposes, derived from their own suffrages, will of course be allowed them; and as the authority of the legislature of the State, and of the inhabitants of the ceded part of it, to concur in the cession, will be derived from the whole people of the State in their adoption of the Constitution, every imaginable objection seems to be obviated .... The necessity of a like authority over forts, magazines, etc., established by the general government, is not less evident .... All objections and scruples are here also obviated, by requiring the concurrence of the States concerned, in every such establishment.

The Federalist No. 43 (James Madison) (Clinton Rossiter ed., 1961) (emphasis added).

50 See Natelson, supra note 4, at 95-96 (discussing grants through words of obligation in Articles IV \& VI of the Constitution).

${ }^{51} \quad$ See U.S. CONST. art. III, $\$ 2$, cl. 3 ("The Trial of all Crimes, except in Cases of Impeachment, shall be by Juryl.l"); $i d$. amend. V ("No person shall be held to answer for a capital, or otherwise infamous crime, unless on a presentment or indictment of a Grand Jury [.]"); id. amend. VI ("In all criminal prosecutions, the accused shall enjoy the right to a speedy and public trial, by an impartial jury[.]”); $i d$. amend. VII ("In Suits at common law, where the value in controversy shall exceed twenty dollars, the right of trial by jury shall be preserved[.|”). 


\section{SOME COMMON CHARACTERISTICS OF FEDERAL FUNCTIONS}

An actor exercising a federal function derives his, her, or its authority from the portion of the Constitution empowering the actor. The courts have made this clear by rejecting claims that a state legislature's authority in the amendment process is a power reserved by the Tenth Amendment ${ }^{52}$ and therefore subject to state law. ${ }^{53}$ Similarly, the power to direct the method for choosing presidential electors "is conferred upon the legislatures of the states by the constitution of the United States, and cannot be taken from them or modified by their state constitutions. ${ }^{{ }^{54} 4}$ When Congress exercises Article V functions, it also acts as an independent assembly-not as the legislature empowered by other portions of the Constitution. ${ }^{55}$

Explicit powers devolving federal functions carry with them incidental authority, just as explicit powers elsewhere in the Constitution do. ${ }^{56}$ The scope of incidental authority is defined by custom and necessity. ${ }^{57}$

The courts frequently have adjudicated the question of whether the grant of a federal function carries with it a particular incidental power. The issue has surfaced most often in cases involving the amendment process. For example, if Congress selects the convention mode of ratifying a proposed

See U.S. CONST. amend. X ("The powers not delegated to the United States by the Constitution, nor prohibited by it to the States, are reserved to the States respectively, or to the people."); see also United States v. Sprague, 282 U.S. 716, 733 (1931) (holding the Tenth Amendment is inapplicable to Article V); United States v. Thibault, 47 F.2d 169, 172 (2d. Cir. 1931) (holding the Tenth Amendment is inapplicable to Article V); McPherson v. Blacker, 146 U.S. 1, 34-35 (1892) (holding that electors receive their power directly from the Constitution).

53 Courts have consistently held that the legislature is free to disregard state rules when ratifying an amendment. See, e.g., Leser v. Garnett, 258 U.S. 130, 137 (1922); Hawke v. Smith, 253 U.S. 221, 230 (1920); Trombetta v. Florida, 353 F. Supp. 575, 577-78 (M.D. Fla. 1973); Dyer v. Blair, 390 F. Supp. 1291, 1303 (N.D. Ill. 1975); Walker v. Dunn, 498 S.W.2d 102 (Tenn. 1972).

McPherson, 146 U.S. at 35.

See supra note 30 and accompanying text.

${ }_{36}$ Dillon v. Gloss, 256 U.S. 368, 373 (1921) (holding that Congress has power to limit time for ratification as incidental to its selection of a mode of ratification because in Article $\mathrm{V}$ "what is reasonably implied is as much a part of it as what is expressed"); $c f$. Chiafalo v. Washington, $140 \mathrm{~S}$. Ct. 2316, 2320 (2020) (holding each state's power to determine the method of choosing its presidential electors includes the unstated power of dictating how they vote).

${ }^{57}$ See Robert G. Natelson, Legal Origins of the Necessary and Proper Clause, in The Origins of the Necessary and Proper Clause 52, 60-66 (2010) (exploring the origin and scope of incidental powers); cf. Chiafalo, $140 \mathrm{~S}$. Ct. at 8 ("history" and "[L]ongstanding practice"); id. at 8 ("the Nation's history"); id. at 12 (citing practice "for centuries now"); id. at 13 ("Long settled and established practice"). 
amendment, the state legislatures enjoy incidental authority to constitute ratifying conventions for their states. ${ }^{58}$ In like manner, a legislature or convention serving an Article $\mathrm{V}$ function has the well-recognized prerogative of adopting its own rules of suffrage and procedure..$^{59}$ Because a convention for proposing amendments is a "convention of the states," ${ }^{90}$ presumably state legislatures enjoy the incidental federal functions of deciding how their states' commissioners are selected and instructed-state legislative prerogatives universal in the convention of states setting. ${ }^{61}$ Of course, these Article V cases are merely specific applications of the wider principle that implied authority follows express powers. ${ }^{62}$

However, no person or entity has incidental powers that would defeat or impair the constitutional functions of other persons or entities. ${ }^{63}$ For example, fixing the time and place of meeting is incidental to Congress's power to call an amendments convention. ${ }^{64}$ However, treating the dictation of rules and other procedures to the convention as incidental to the call, as some have suggested, ${ }^{65}$ would undercut the convention's intended role as a way to bypass

${ }_{58} \quad$ State ex rel. Donnelly v. Myers, 186 N.E. 918 (Ohio 1933) (stating that the calling of a convention is an incidental duty of the state legislature when Congress chooses that mode of ratification).

${ }^{59} \quad$ Dyer v. Blair, 390 F. Supp. 1291, 1307-08 (N.D. Ill. 1975).

60 Smith v. The President \& Dirs. of the Union Bank of Georgetown, 30 U.S. 518, 528 (1831); see State v. Foreman, 16 Tenn. 256, 304 (1835) (referring to the 1788 North Carolina convention to ratify proposed amendments as a "convention of the states").

61 Natelson, Mystery, supra note 9, at 4; Natelson, Rules, supra note 9, at 693.

62 Ex parte Yarbrough, 110 U.S. 651, 658 (1884) (enlisting "the doctrine universally applied to all instruments of writing, that what is implied is as much a part of the instrument as what is expressed" to conclude that congressional powers are implied by the Elections Clause).

${ }_{63}$ See Howard Jarvis Taxpayers Ass'n v. Padilla, 363 P.3d 628, 634 (Cal. 2016) (holding that a state legislature acting under Article $\mathrm{V}$ enjoys an incidental power to investigate, but that

The investigative power is not unlimited. While the Legislature's powers and functions are extensive ..., they must share space with powers reserved to the executive and judicial branches. Although the Legislature's activities can overlap with the functions of other branches to an extent, the Legislature may not use its powers to "defeat or materially impair" the exercise of its fellow branches' constitutional functions, nor "intrude upon a core zone" of another branch's authority.").

Cf. Printz v. United States, 521 U.S. 898, 923-24 (1997) (holding that a congressional measure invading the constitutional sovereignty of the states is not a validate exercise of congressional incidental power under the Necessary and Proper Clause, U.S. CONST. art. I, § 8, cl. 18, because such a measure is not "proper").

${ }_{64}$ Natelson, Conventions, supra note 9, at 629; NATELSON, LAW OF ARTiCle V, supra note 9, at 5558 .

${ }^{65} \quad$ See, e.g., Charles L. Black, Jr., The Proposed Amendment of Article V: A Threatened Disaster, 72 YALE L.J. 957, 964 (1963) (arguing that 
Congress. ${ }^{66} \quad$ It also would violate the convention's incidental power to determine such matters for itself. ${ }^{67}$

\section{DIFFERENCES AMONG FEDERAL FUNCTIONS}

The principal differences among federal functions are the actors' varying spheres of authority. Spheres of authority vary because each federal function has its own purpose and arises in its own textual and historical context. Thus, for each function the courts deduce the actor's scope of authority from the Constitution's text, the nature of the function, and the historical background. ${ }^{68}$ The following summarizes some of the differences:

A state legislature acting under the Elections Clause may not adopt regulations without the governor's signature (if required by the state constitution). ${ }^{69}$ But a state legislature may undertake its Article $\mathrm{V}$ functions without gubernatorial approval. ${ }^{70}$

In general, it would seem that the exercise of elective functions would be meaningless unless electors may exercise free choice among available candidates. This is obvious in the case of voting for members of Congress, and prior to adoption of the Seventeenth Amendment, state legislators were

"[s]ince Congress is to call the convention, and since no specifications are given, and since no convention can be called without specifications of constituency, mode of election, mandate, majority necessary to 'propose,' and so on, then Congress obviously may and must specify on these and other necessary matters as its wisdom guides it.").

66 Natelson, Rules, supra note 9, at 699-700.

67 Dyer v. Blair, 390 F. Supp. 1291,1307-08 (N.D. Ill. 1975) (holding that a convention may establish its own voting requirements).

68 See, e.g., Bush v. Gore, 531 U.S. 98, 108-112 (2000) (limiting the state power to determine the mode of choosing electors); see also Ray v. Blair, 343 U.S. 214, 229-31 (1952) (defining the scope of the state power to determine the mode of choosing presidential electors); Smiley v. Holm, 285 U.S. 355, 369-72 (1932) (holding that the governor's signature is necessary to regulations under the Elections Clause because of their legislative nature and long acquiescence); Hawke v. Smith, 253 U.S. 221, 227-29 (1920) (examining the historical use of the word "legislature" in Article V); United States v. Thibault, 47 F.2d 169, 171-72 (2d Cir. 1931) (relying on long acquiescence to the practice of proposing and ratifying constitutional amendments).

${ }_{69} \quad$ See Smiley, 285 U.S. at 372-73 (holding that "there is nothing in article 1, $\$ 4$, which precludes a state from providing that legislative action in districting the state for congressional elections shall be subject to the veto power of the Governor").

70 Op. of the Justices to the Senate, 366 N.E.2d 1226, 1229 (Mass. 1977); accord Hollingsworth v. Virginia, 3 U.S. 378, 379 (1798) (explaining that when Congress proposes an amendment the president's signature is not necessary). 
free to choose the Senators they wished. ${ }^{11}$ Recently, however, the Supreme Court reached a "non-obvious" conclusion by upholding state laws dictating the votes of presidential electors; the decision, the Court said, was compelled by long-standing election practice. ${ }^{72}$ In doing so, the Court almost entirely disregarded very substantial evidence that the understanding behind the relevant terms of both the original Constitution and the Twelfth Amendment presupposed elector discretion. ${ }^{73}$

In any event, the scope of an elector's authority is restricted to voting in the election. If, for example, presidential electors tried to propose a constitutional amendment to the states for ratification, that action would be ultra vires. ${ }^{74}$

A convention for proposing amendments creates an interesting contrast to the Electoral College. In one sense, it has a wider scope of authority: It may consider any proposal within the legislative applications of the states that applied for it. But according to the uniform history of similar "conventions of the states," commissioners are unquestionably subject to state legislative instruction. ${ }^{75}$ Moreover, a convention for proposing amendments has only proposal power; other actions would be ultra vires. ${ }^{76}$

A state legislature considering whether to apply for a convention to propose amendments has unfettered discretion on whether to apply and for what amendments to apply. Lawmakers cannot be coerced by voter initiatives or otherwise. ${ }^{77}$ State legislatures are similarly free to ratify or refuse to ratify

71 See e.g., George H. Haynes, The Election OF SENATORs142-47 (Ralph Curtis Ringwalt ed. 1912) (emphasizing that in the decades before adoption of the Seventeenth Amendment, several states allowed voters to register their senatorial preference in general elections. State legislatures frequently elected candidates other than the popular vote winner).

72 Chiafalo v. Washington, 140 S. Ct. 2316, 2328 (2020).

73. Natelson, Discretion, supra note 12.

$74 \quad$ See Fitzgerald v. Green, 134 U.S. 377, 379 (1890) ("The sole function of the presidential electors is to cast, certify, and transmit the vote of the state for president and vice-president of the nation.”).

${ }^{75}$ See Natelson, Conventions, supra note 9, at 631 (explaining that commissioners, like other agents, were expected to remain within the limits of their authority); see also NATELSON, LAW OF ARTICLE $\mathrm{V}$, supra note 9 , at 76 (discussing state legislative instruction of convention commissioners).

${ }^{76} \quad$ See Natelson, Conventions, supra note 9, at 631 ("A convention for proposing amendments could recommend that Congress or the states consider amendments outside the subject-matter assigned to the convention, but those recommendations would be legally void-that is, they would not be ratifiable 'proposals."').

$77 \quad$ See Miller v. Moore, 169 F.3d 1119, 1124 (8th Cir. 1999) (striking down a Nebraska constitutional provision as "an unconstitutional attempt effectively to remove Article $\mathrm{V}$ power from legislators and 
constitutional amendments. $^{78} \quad$ State legislatures may sponsor advisory referenda, ${ }^{79}$ but are, of course, limited to ratifying amendments that are duly proposed.

The scope of authority of delegates to a ratifying convention is structured differently yet: They are limited to the purposes of their call (an up-or-down vote on the proposed amendment) but within that limit they are free to exercise discretion. ${ }^{80}$ Federal juries are similar in that their authority is sharply restricted and consists mostly of exercising free discretion in casting an up-ordown vote. Congressional electors are restricted to voting for candidates for Congress, although they have free discretion within that narrow scope.

State legislatures apparently may rescind ratification of a proposed amendment before three fourths of the states have ratified ${ }^{81}$ and are free to rescind applications for a convention before two thirds of the states have applied..$^{82}$

The courts have enlisted both history and constitutional text to determine that a state legislature may not yield to a popular referendum the legislative

to place it in the hands of the people”); Donovan v. Priest, 931 S.W.2d 119, 127 (Ark. 1996) (“[T]the framers of the Constitution chose to give voters no direct role in the amending process; legislatures alone received the power to . . r ratify amendments.”) (emphasis omitted); Bramberg v. Jones, 978 P.2d 1240, 1251 (Cal. 1999) (holding that voters of a state may not mandate the operation of the federal Constitutional process); Am. Fed'n of Labor-Cong. of Indus. Orgs. v. Eu, 686 P.2d 609, 61314 (Cal. 1984) (emphasizing that the electorate has no power to compel legislative action); Op. of the Justices, 673 A.2d 693, 698 (Me. 1996) (noting that the state Legislature may not interfere with the exercise of delegated authority with respect to specific voter initiatives); State ex rel. Harper v. Waltermire, 691 P.2d 826, 831 (Mont. 1984) ("The people through initiative cannot affect the deliberative process."); In re Initiative Petition No. 364, 930 P.2d 186, 193 (Okla. 1996) (arguing that "[t]he initiative measure does not propose a law"); League of Women Voters v. Gwadosky, 966 F. Supp. 52, 62 (D. Me. 1997) (explaining that state ballot labeling laws were an attempt to coerce state legislators to vote for the people's choice).

78 Leser v. Garnett, 258 U.S. 130, 137 (1922); see Hawke v. Smith, 253 U.S. 221, 231 (1920) (holding that state legislators do not have authority to require ratification of constitutional amendments); Decher v. Vaughan, 177 N.W. 388, 391-92 (Mich. 1920) (emphasizing that the action of state legislators in ratifying amendments is not required).

$79 \quad$ Howard Jarvis Taxpayers Ass'n v. Padilla, 363 P.3d 628, 646 (Cal. 2016).

so In re Op. of the Justices, 167 A. 176, 180 (Me. 1933) ("The convention must be free to exercise the essential and characteristic function of rational deliberation.").

${ }^{81}$ Idaho v. Freeman, 529 F. Supp. 1107, 1150 (D. Idaho 1981), vacated as moot, Carmen v. Idaho, 459 U.S. 809 (1982).

${ }^{82}$ See Padilla, 363 P.3d at 650 ("[W]hat the Legislature has enacted, it may repeal" (alteration in original) (citation omitted)). 
power to establish a ratifying convention. ${ }^{83}$ The Supreme Court of Maine enlisted the same sources to determine that a state legislature authorizing a ratifying convention must provide for delegate-selection by district rather than at large. ${ }^{84}$

When a state exercises its legislative function under the Elections Clause, its scope of authority is constrained by the fact that Congress may override state regulations. ${ }^{85}$ It is further constrained by constitutional rules prohibiting certain regulations. $^{86}$

Finally, a governor's administrative function in issuing writs of election to fill congressional vacancies is also limited. In the usual case, issuing such a writ is mandatory, and refusing to do so is outside the governor's scope of authority. ${ }^{87}$ In marked contrast to the functions delegated to state entities by Article V, a governor's appointive function of filling Senate vacancies is controlled in part by state law. ${ }^{88}$

\section{CONCLUSION}

The prominence in the Constitution of the list of congressional powers in Article I, Section 8 sometimes overshadows the fact that the document enumerates powers in various other places, including grants of authority to actors not part of the federal government at all. The courts characterize the execution of these powers as "federal functions."

83 In re Op. of the Justs., 107 A. 673,675 (Me. 1919); see In re Op. of the Justs., 172 S.E. 474,478 (N.C. 1933) (discussing the scope of a legislature's authority to constitute a ratifying convention); State ex rel. Donnelly v. Myers, 186 N.E. 918 (Ohio 1933) (holding that calling a convention to ratify proposed amendments is a federal function, in which the absence of Congress, the state legislature has the authority to perform).

s. In re Op. of the Justs., $107 \mathrm{~A}$. at 674.

25 U.S. CONST. art. I, $\$ 4$, cl. 1.

${ }_{86} \quad$ U.S. Term Limits, Inc. v. Thornton, 514 U.S. 779, 808-11 (1995) (holding that state legislatures acting under the Elections Clause could not add qualifications for members of Congress beyond those listed in the Constitution).

${ }_{87}$ Judge v. Quinn, 612 F.3d 537, 547 (7th Cir. 2010); see Am. C.L. Union of Ohio, Inc. v. Taft, 385 F.3d 641, 649 (6th Cir. 2004) (holding issuing a writ to fill a vacancy in the House is mandatory); Jackson v. Ogilvie, 426 F.2d 1333, 1336-37 (7th Cir. 1970) (holding that the defendant had a duty, at the time of death of the Representative, to issue a writ to fill his vacancy).

${ }_{88}$ Valenti v. Rockefeller, 292 F. Supp. 851, 861 (S.D.N.Y. 1968); see Tedards v. Ducey, 398 F. Supp. 3d 529, 535 (D. Ariz. 2019) (explaining that the Seventh Amendment of the Constitution gives "state legislatures the authority to establish procedures for filling vacancies in Senate"). 
Federal functions exercised by non-federal actors fall into eight classes: electoral, appointive, proposing, ratifying, administrative, legislative, consenting, and judicial. They all share two characteristics. One is that the authority for executing them comes directly from the Constitution, and not from state constitutions or state or federal law-although in some cases the relevant constitutional provision explicitly authorizes regulation by state law. Another common characteristic is that the grants creating the functions, like other power grants in the Constitution, include limited incidental, implied authority.

Otherwise, these functions differ substantially. One illustration is the scope of discretion exercised by each designated actor. For example, although state legislatures may control the discretion of both presidential electors and amendments convention commissioners, presidential electors are limited to a very narrow agenda, while state applications for a convention for proposing amendments generally offer that convention a broader scope. Similarly, a state legislature determining how presidential electors or amendments convention commissioners are chosen has wide discretion, but a state legislature determining whether to ratify a proposed amendment-like a federal jury determining guilt or innocence-may cast only an up-or-down vote. In each case, the scope of authority is determined by the language the Constitution employs, the nature of the function, and the history behind it. 